\title{
FDA seeks to close xenotransplant gap
}

[WASHINGTON] Ways to minimize the risks that transplanting animal organs into humans could trigger a new disease pandemic were discussed at a meeting to help build bridges between scientists and transplant surgeons last week.

The US government will revise its guidelines on xenotransplantation by the end of this year, partly on the basis of a dialogue between surgeons, who are eager to experiment with it, and virologists, some of whom fear that such transplants could transfer new infectious diseases to the human population, and perhaps trigger new pandemics.

The meeting was held in Bethesda, Maryland, by US government agencies to help establish such a dialogue. It heard that possible routes to reducing risk included the breeding of virus-free herds of donor animals, and the vaccination or antibody treatment of patients to eliminate virus from their blood after they receive a transplant.

Officials said that the two-day meeting had established a better understanding between surgeons and virologists. "We were quite pleased with the process," says Phil Noguchi, a senior official at the Food and Drug Administration (FDA), who helped to organize the meeting. "I'd say the virologists were somewhat less conservative than we might have expected."

But several virologists at the meeting said that the public health risks of xenotransplantation are very difficult to assess. Preston Marx of the Aaron Diamond AIDS Research Center in New York, who spoke about his studies of cross-species infection, said afterwards that the risks could be reduced but not eliminated.

Marx said that viruses have been trans- ferred from animals to humans - by biting or blood-to-blood contact, for example throughout history. But the result is usually a "dead-end infection", he says, as the virus is not transmitted between humans.

Experiments on the impact of transplants from pigs, the most likely animal donor species, to non-human primates could be useful. According to Ron Ferguson, a transplant surgeon at Ohio State University: "Primate trials with pig organs could well answer some of these questions and give some realism to policy, rather than having a policy based on fear of the unknown."

Draft guidelines on xenotransplants were published by the US Public Health Service last year, but some virologists say they are insufficiently restrictive. They point out that the transfer of viruses between species is inevitable: recent in vitro research at the Institute of Cancer Research in London, for example, demonstrated that a pig retrovirus can be infectiously transmitted to human cells (see Nature Medicine 3, 282-286; 1997).

But the actual risk that pig virus could then be transmitted between humans and cause disease is unknown. "We need to be creative in finding ways to define the risks in a form that the public can deal with," said Jay Fishman, a surgeon and researcher at the Massachusetts General Hospital in Boston. "If we don't collaborate openly, it will be very difficult to convince the public that we're not hiding something."

But some surgeons are impatient with scientists' efforts to assess risks that surgeons see as hypothetical. Ferguson reminded the meeting that transplantation was launched, as a medical practice, by doctors in London

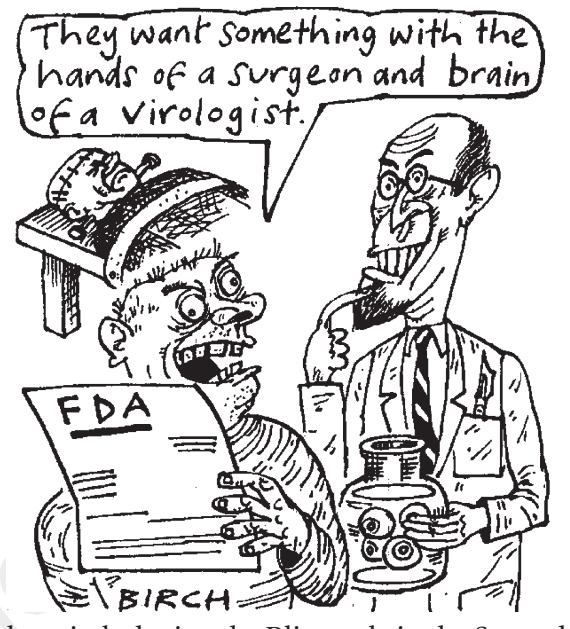

hospitals during the Blitz early in the Second World War, and implied that it has been working over the objections of scientists ever since. "We have the history to sit down with another discipline, and mould something good," he said.

William Raub, deputy assistant secretary at the Department of Health and Human Services, promised that the meeting would help the department to prepare new guidelines "within the next several months" that would include rules for assessing the risks of each proposed research protocol.

About a dozen research protocols are under way in the United States, mostly involving pig cells and tissues and none involving human patients. Each has had to be approved individually by the FDA. The health department plans another workshop in the autumn, with patient representatives and regulators as well as scientists and surgeons, to discuss xenotransplant policy.

Colin Macilwain

\section{University settles with patients over trade in 'stolen' embryos}

[SAN FRANCISCO] The University of California has settled, at a cost of about \$14 million, 72 lawsuits filed by former patients of its fertility clinics at San Diego and Irvine, where two years ago it was alleged that eggs and embryos were stolen and implanted into other women or used for research.

Details of the agreement were not disclosed, under an order from the California Supreme Court to protect the privacy of the couples involved. According to the lawsuits, doctors at the clinics had given eggs to other couples without the consent of the women from whom they were taken (see Nature 376, 456; 1995 \& 379, 756; 1996).

In addition, patients were included in research studies without their consent; drugs not approved by US regulators were sold to patients; and informed consent for medical procedures was at best sloppy and poorly documented. As a result, children were born without the knowledge of the women who had produced their eggs.

The agreement must still be approved by Orange County Superior Court. James Holst, general counsel for the university, said in a statement that the university would continue to pursue settlement in the 30 cases remaining.

The Irvine Center for Reproductive Health is now closed, and the university's San Diego programme has reopened under new leadership, after being closed two years ago.

The three principal doctors in the case continue to face criminal charges and have been indicted on federal charges of mail fraud and income tax evasion. Two have left the country: Ricardo H. Asch is in Mexico and Jose P. Balmaceda is in Chile. Serio C. Stone is under house arrest in California. All have denied wrongdoing, and blame university officials for any paperwork mix-ups.
According to Laurel Wilkening, chancellor at the University of California at Irvine, the money for the settlement comes out of an insurance liability fund paid into by university medical centres. Tenet Healthcare Corporation, which now owns the hospital in which many of the cases originated, has agreed to help with the payment.

University officials say that the funds would not have been spent for any other purpose. But Gray Davis, California's lieutenant governor and an ex-officio member of the university Board of Regents, complained to reporters that taxpayers were once again paying to clean up a university management failure. He said managerial and fiscal controls must be improved.

In the wake of the scandal, the university set up task forces to look into supervision of research and quality of care at fertility centres.

Sally Lehrman 